
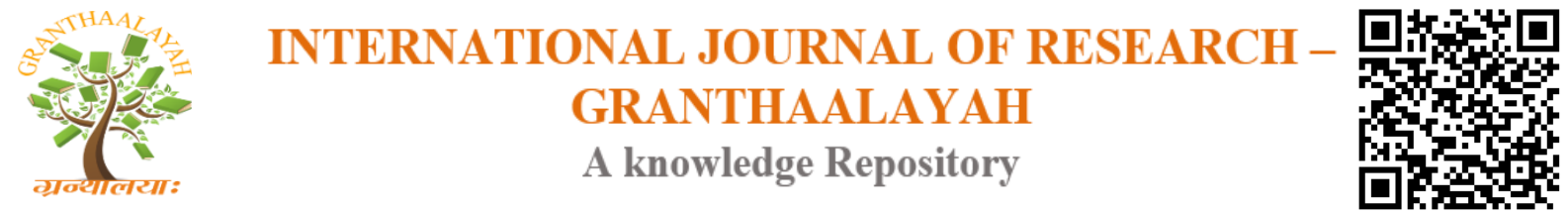

Science

\title{
ADAPTABILITY STUDY OF IMPROVED ONION (ALLIUM CEPA L.) VARIETIES AT SOUTH ARI WOREDA OF SOUTH OMO ZONE, ETHIOPIA
}

\author{
Misgana Mitiku *1, Awoke Tadesse ${ }^{2}$ \\ ${ }^{*}$ Department of Plant Pathology, Southern Agricultural Research Institute, Jinka Agricultural \\ Research Center, P.O.BOX 96, Jinka, Ethiopia \\ ${ }^{2}$ Department of Agronomy, Southern Agricultural Research Institute, Jinka Agricultural \\ Research Center, P.O.BOX 96, Jinka, Ethiopia
}

\begin{abstract}
Onion varieties were evaluated for adaptability to the climatic conditions in South Ari woreda. Three varieties of onion were planted under a complete randomized block design experiment with three replications at research field in Jinka Agricultural research Center (South Ari woreda of South Omo zone SNNPRS of Ethiopia). The quantitative data on bulb yield, plant height, bulb size and number of leaves of onion varieties were collected. All the varieties were harvested at their maturity (90\% tops down) and then weighed. Statistical methods were used for data analysis where by analysis of variance was applied. It was concluded that the three varieties (treatment) combinations, namely Adama red, Nasick red and contribute similarly to the total yield, plant height, number of leaves and bulb size. The variety local was the best onion variety as it produced the highest bulb yield of $3.3167 \mathrm{~kg} / \mathrm{plot}$ numerically. Based on varietal characteristics of relative bulb size, good yield, easy availability of seeds and cheaper price of seeds in the local market, we recommend farmers to use local variety followed by Nasick red and Adama red therefore, government should promote these onion varieties for cultivation in South Ari especially for jinka and its vicinity. Government can import to ensure the availability of Local and Nasick red varieties so that farmers can be motivated for adoption of these varieties for commercial production. The effects of different planting dates on the yield of onion varieties can be considered for future research.
\end{abstract}

Keywords: Onion; Onion Productivity; Onion Varieties; Research Field Evaluation; Adaptation; Yield Performance; South Ari.

Cite This Article: Misgana Mitiku, and Awoke Tadesse. (2017). "ADAPTABILITY STUDY OF IMPROVED ONION (ALLIUM CEPA L.) VARIETIES AT SOUTH ARI WOREDA OF SOUTH OMO ZONE, ETHIOPIA.” International Journal of Research - Granthaalayah, 5(7), 541-545. https://doi.org/10.29121/granthaalayah.v5.i7.2017.2162. 


\section{Introduction}

The common bulb onion, Allium cepa $L .(2 n=2 x=16)$.Its belongs to family Alliaceae, an important group of crops worldwide [3]. It is one of the oldest bulb vegetables in continuous cultivation dating back to at least $4000 \mathrm{BC}[2,4]$.It is probably native of South Asia or Mediterranean region. It is considerably important in the daily Ethiopian diet [12]. All the plant parts are edible, but the bulbs and the lower stems sections are the most popular as seasonings or as vegetables in stews. It is recently introduced crop and rapidly becoming popular among producers and consumers. It is widely produced by small farmers and commercial growers throughout the year for local use and export market [7].

Onion is valued for its distinct pungency and from essential ingredients for flavoring varieties of dishes, sauces, soup, sandwiches, snacks as onion rings etc. The crop nutritional composition includes $2.0 \mathrm{~g}$ protein, $70 \mathrm{mg}$ calcium and $53 \mathrm{mg}$ phosphorus [1]. It also contains the vitamins thiamine, riboflavin and niacin and is used for its medicinal value especially in the case of heart problems [9]. They also contain a phytochemical called quercetin, which is effective in reducing the risk of cardiovascular disease, an anticancer, and has promise to be an antioxidant [11]. It is popular over the local shallot because of its high yield potential per unit area, availability of desirable cultivars for various uses, ease of propagation by seed, high domestic(bulb and seed) and export(bulb, cut flowers) markets in fresh and processed forms [8].

Onion contributes too substantially to the national economy, apart from overcoming local demands. Products like bulbs and cut flowers are exported to different countries of the world. With the growing irrigated agriculture in the country, there is a great potential for extensive onion seed and dry bulb production in the different production belts of the country [12]. Onion prefers well-drained sandy loam with a high content of organic matter. The optimum altitude range for onion production is between 700 and 2200 m.a.s.l and the optimum growing temperature lies between $15^{\circ} \mathrm{c}$ and $23^{\circ} \mathrm{c}$ [10]. The total area under production during2012/13 cropping season, reaches over $21,865.37$ hectares and the production is estimated to be over 2,191,886.02 quintals [8]. Even if, the zone is endowed with mentioned agro-ecologies and has valuable resource for onion production.

There are a number of production problems which makes the farmers not to produce onion in advanced manner. Among those production problem the low yield because of non-optimal agronomic practices, unavailability and high cost of seed, the prevalence of diseases and insect pests, lack of improved varieties and more improved production technologies. Therefore, the objective of the study was to evaluate the performance and adaptability of the improved onion varieties and to select the high yielding variety/ies from the tested varieties.

\section{Material and Method}

\subsection{Description of the Study Area}

The experiment was conducted at Jinka Agricultural Research Center research field. It is located $550 \mathrm{~km}$ away from the administrative town of Southern nation and nationalities people's regional state. Jinka is located at $5^{\circ} 52^{\prime} \mathrm{N}, 36^{\circ} 38^{\prime} \mathrm{E}$, and $1450 \mathrm{~m}$ above sea level with annual average 
rainfall and temperature of $900 \mathrm{~mm}$ and $22.3^{\circ} \mathrm{C}$, respectively. The soil of the experimental field is sandy loam (SOARDO).

\subsection{Experimental Procedures}

Two improved onion varieties and one local check (ferensay) were planted at recommended seeding rate of $4 \mathrm{~kg} / \mathrm{ha}$ on March, 2014.A randomized complete block design with three replication was used. Seeds of three varieties of onion namely: Adama red, Nasick red and local (Ferensay) were sown on seed bed. At four leaves stage or pencil thickness seedlings were transplanted in plot of $3.2 \mathrm{~m} \times 3.2 \mathrm{~m}$. Each plot consists of eight rows with 3.2 meter long. Row to row and plant to plant spacing was $40 \mathrm{~cm}$ and $20 \mathrm{~cm}$ respectively. Prior to transplanting, $100 \mathrm{~kg} / \mathrm{ha}$ of DAP and half of Urea which is $75 \mathrm{~kg} / \mathrm{ha}$ was applied before planting and the remaining half of urea $(75 \mathrm{~kg} / \mathrm{ha})$ was applied six weeks or 45 days after transplanting. All the recommended cultural practices in growing period of onion were applied. However, no farm chemical was applied as all the varieties were growing healthy and no pest and diseases problem was observed. All varieties were harvested once as per their maturity stage (90\% tops down).The harvested bulb of all varieties were left to dry in shade for four days then the leaves were removed to get the dry bulbs of onion. The quantitative data on yield and yield components were analyzed using analysis of variance; SAS program verssion9.1.Treatment means were separated using Duncan Least Significant Difference (LSD).

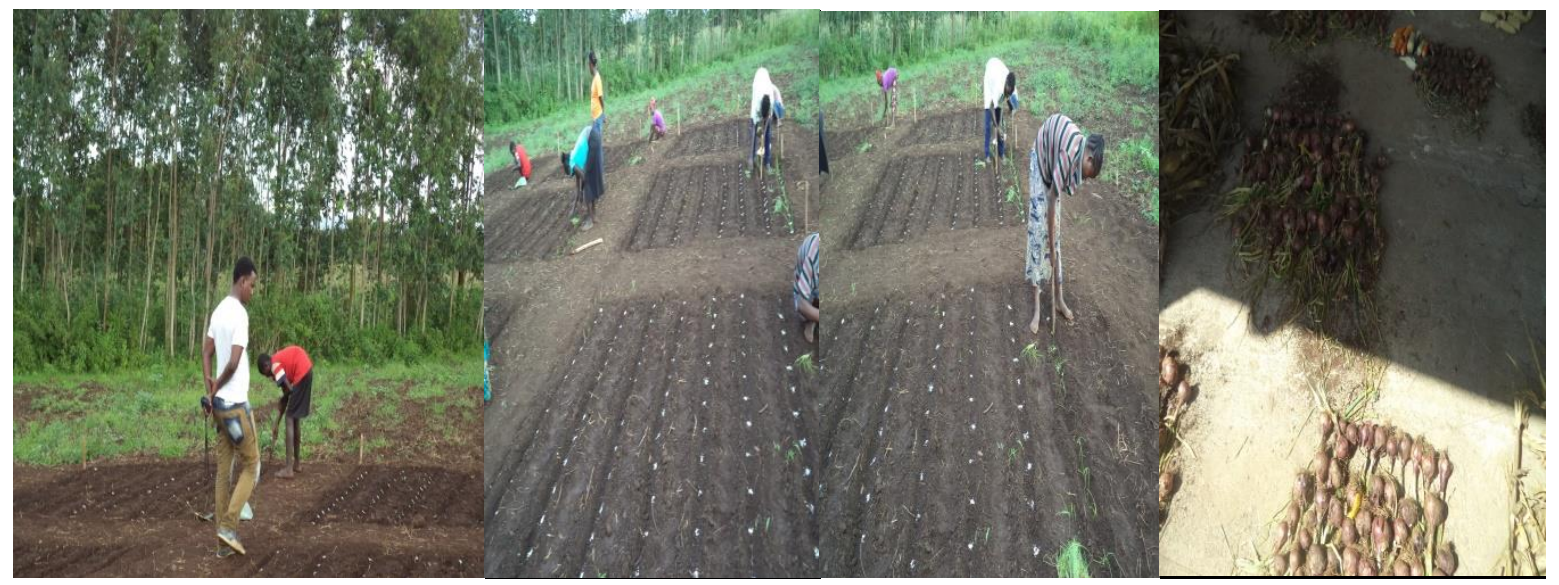

Figure 1: Field preparation, transplanting of onion seedlings and harvested onion bulb

\section{Result and Discussion}

Analysis of variance was conducted to examine whether the three onion varieties differ significantly for their total yield, plant height, number of leaves and bulb size. The results of analysis variance for their total yield, plant height, number of leaves and bulb size in Table 1, and Table 2 respectively. Table 1 and table 2 reveals that total yield, plant height, number of leaves and bulb size of three onion varieties are not significantly differ $(\mathrm{p}<.05)$. Also there is no significant effect of the replications. Therefore, it can be concluded that the three variety (treatment) combinations, namely Adama red, Nasick red and contribute similarly to the total yield, plant height, number of leaves and bulb size. Also the total bulb yield, plant height, number of leaves and bulb size of onion does not seem to be impacted by the layout of experiment in the field and its conduction. It implies that the onion varieties do not responded to 
the climatic conditions of South Ari woreda and reflected non significantly their productivity performance. These results are disagree with the findings of $[5,6]$ reported that various cultivars of the same species grown in the same environment give different yields as the performance of a cultivar mainly depends on the interaction of genetic makeup and environment. The person correlation coefficient analysis revealed that number of leaves has positive and non-significant correlation with plant height but, it didn't have correlation with bulb size and bulb yield (Table3). Whereas bulb size has negative and non-significant correlation with plat height but it has positive non-significant correlation with number of leaves also it didn't has correlation with bulb yield (Table3).

While bulb yield has negative non-significant correlation with plant height but it has positive non-significant correlation with number of leaves and bulb size.

Table1: Significances of mean square values for 4 agronomic traits for 2 improved onion varieties and one local check.

\begin{tabular}{|l|l|l|l|l|l|}
\hline \multicolumn{1}{|c|}{ Source of variation } & \multicolumn{1}{c|}{ DF } & \multicolumn{1}{c|}{ Ph.(cm) } & \multicolumn{1}{c|}{ NL } & \multicolumn{1}{c|}{ BS } & \multicolumn{1}{c|}{ BY } \\
\hline Replication & 2 & $19.0401 \mathrm{~ns}$ & $1.29298 \mathrm{~ns}$ & $0.49653 \mathrm{~ns}$ & $2.30858 \mathrm{~ns}$ \\
\hline Treatment & 2 & $6.1725 \mathrm{~ns}$ & $1.37408 \mathrm{~ns}$ & $0.31710 \mathrm{~ns}$ & $1.19308 \mathrm{~ns}$ \\
\hline Error & 4 & 41.2703 & 2.41454 & 0.09193 & 0.55506 \\
\hline $\mathrm{Cv}$ & & 15.14 & 15.81 & 3.44 & 26.78 \\
\hline
\end{tabular}

Note: $\mathrm{Ph} .=$ plant height in $\mathrm{cm}, \mathrm{NL}=$ number of leaves, $\mathrm{BS}=$ bulb size in $\mathrm{cm}, \mathrm{BY}=$ bulb yield and ns=no significant difference

Table 2: Mean values of Plant height, Number of leaves, Bulb size and bulb yield for the tested varieties.

\begin{tabular}{|l|l|l|l|l|}
\hline \multicolumn{1}{|c|}{ Treatments } & \multicolumn{1}{c|}{ PH $(\mathbf{c m})$} & \multicolumn{1}{c|}{ NL } & \multicolumn{1}{c|}{ BS $(\mathbf{c m})$} & BY(kg/plot) \\
\hline Local & $42.830 \mathrm{~A}$ & $10.273 \mathrm{~A}$ & $8.6800 \mathrm{~A}$ & $3.3167 \mathrm{~A}$ \\
\hline Adama red & $40.827 \mathrm{~A}$ & $9.050 \mathrm{~A}$ & $8.5700 \mathrm{~A}$ & $2.0867 \mathrm{~A}$ \\
\hline Nasick red & $43.607 \mathrm{~A}$ & $10.163 \mathrm{~A}$ & $9.1800 \mathrm{~A}$ & $2.9433 \mathrm{~A}$ \\
\hline Critical Value for Comparison & $14.563 \mathrm{~A}$ & $3.5226 \mathrm{~A}$ & $0.6874 \mathrm{~A}$ & $1.6889 \mathrm{~A}$ \\
\hline
\end{tabular}

Note: There are no significant pairwise differences among the means. Means with the same letter are not significantly different

Table3: Pearson Correlations Analysis

\begin{tabular}{|c|c|c|c|c|}
\hline & PH & NL & BS & BY \\
\hline Ph & 1.0000 & & & \\
\hline Nl & 0.6543 & 1.0000 & & \\
\hline Bs & -0.1456 & 0.2722 & 1.0000 & \\
\hline By & -0.0514 & 0.6295 & 0.6513 & 1.0000 \\
\hline
\end{tabular}

Note: $\mathrm{PH}=$ plant height, $\mathrm{NL}=$ number of leaves, $\mathrm{BS}=$ bulb size and $\mathrm{BY}=$ bulb yield

\section{Conclusion and Recommendation}

The results indicated that all three onion varieties were not statistically significantly different from each other for their bulb yield but, the variety local was the best onion variety as it produced the highest bulb yield of $3.3167 \mathrm{~kg} / \mathrm{plot}$ numerically. Based on varietal characteristics 
of relative bulb size, good yield, easy availability of seeds and cheaper price of seeds in the local market, we recommend farmers to use local variety followed by Nasick red and Adama red. Observing the numerical value of the yield, it can be concluded that Local is be the best onion variety followed by Nasick red which can improve onion production in South Ari woreda and therefore should be promoted for cultivation in South Ari woreda of South Omo zone of Southern Nations and Nationality People Regional state of Ethiopia. The Ministry of Agriculture along with the potential farmers across the country provides can effective platform for development and evaluation of onion new varieties. Planting dates can be a determining factor in productivity performance of the onion varieties and therefore; effects of different planting dates on yield of onion varieties especially, Local and Nasick red should be considered for future research.

\section{References}

[1] Ado, P.O. 2001. Onion cultivation. Onion Newsletter, 20: 30-34.

[2] Ahmad, S., Chohan, T.Z. and Saddozai, K.N.2008. An investigation into cost and revenue of onion production in Azad Jammu Kashmir. Sarhad Journal of Agriculture, 24 (4): 737-743.

[3] Best, K. 2000. Red Onion Cultivars Trial. Horticultural Nova Scotia, Kentville Agricultural Centre, Nova Scotia, Canada. pp. 10-13.

[4] Hayslip, N.C., Gull, D.D., Guzman, V.L., Shumaker, J.R. and Sonoda, R.M.1987. Bulb onion production in Florida. FL Coop. Ext. Svc. Bull. 238 p.

[5] Jilani, M.S. and Ghafoor, A. (2003). Screening of Local Onion Varieties for Bulb Formation. International Journal of Agriculture and Biology, 5 (2), 129-133.

[6] Kimani, P.M., Kariuki, J.W., Peters, R. and Rabinowitch, H.D. (1993). Influence of the Environment on the Performance of Some Onion Cultivars in Kenya. African Crop Science journal, 1(1), 15-23.

[7] MARD.2008. Ministry of Agriculture. Animal and Plant Health Regulatory Directorate. Crop varieties register Issue No, 11. June 2008. Addis Ababa, Ethiopia.

[8] MARD. 2010. Ministry of Agriculture. Animal and Plant Health Regulatory Directorate. Crop varieties register Issue No, 13. June, 2010. Addis Ababa, Ethiopia.

[9] Mettananda, K.A. and Fordham, R. 2001. The Effects of Plant Size and Leaf Number on the Bulbing of Tropical Short-day Onion Cultivars (Allium cepa L.) Under Controlled Environments. Journal of Horticultural Science, 14(5), 22-31.

[10] Prasad and Kumar. 2005. Principles of Horticulture.2nd ed. Rajasthan Agriculture University Bikaner-334006. Managing Director Agro bios India, Jadhupur.

[11] Smith, C. 2003. Genetic Analysis of Quercetin in Onion (Allium cepa L.) 'Laddy Raider. The Texas Journal of Agriculture and Natural Resource, 16, 24-28.

[12] S.Rajan and B.Lissy Markose.2007.Horticulture science series-6.Propagation of Horticultural crops, pp135-136.2nd Ed. New Indian publication Agency.2007. Pitam Pura, New Delhi-11008

\footnotetext{
*Corresponding author.

E-mail address: misganamitiku441@ gmail.com
} 